\title{
Non-clinical study of the anxiolytic effect of Citrus aurantium L. essential oil in an inclusion complex with 2-hydroxypropyl- $\beta$-cyclodextrin
}

\author{
Gabriel Chaves Neto ${ }^{1 *}$ (D), Humberto Hugo Nunes de Andrade ${ }^{1}$ (D) , João Euclides Fernandes Braga ${ }^{1}$ (D), \\ Lucindo José Quintans Júnior ${ }^{2}$ (D), Reinaldo Nóbrega de Almeida ${ }^{1}$ (1), \\ Margareth de Fátima Formiga Melo Diniz ${ }^{1}$ (1) \\ ${ }^{1}$ Laboratório de Psicofarmacologia, Instituto de Pesquisa em Fármacos e Medicamentos, Universidade Federal da Paraíba \\ João Pessoa, PB, Brasil \\ ${ }^{2}$ Departamento de Fisiologia (DFS), Universidade Federal de Sergipe, São Cristovão, SE, Brasil \\ *Corresponding author: gabrielchavesufpb@hotmail.com
}

\begin{abstract}
Anxiety in the world population has increased significantly; the problem has encouraged studies regarding innovative alternatives for treatment. Research with Citrus aurantium L. essential oil (CEO) has revealed positive results with anxiolytic effects in both animals and humans. However, certain limitations affect its storage and preservation, its efficiency in therapy, and determination of adequate posologies. The potential use of cyclodextrins as drug carriers has been successfully explored. This study aims to assess the anxiolytic potential of a CEO/2-hydroxypropyl- $\beta$-cyclodextrin (HP- $\beta$-CD) inclusion complex. Preparation of the inclusion complex was performed using the Alpha 1-2 LDplus lyophilizer. To allow formation, and avoid loss of volatiles to the atmosphere, Limonene (LIM), the main compound in CEO, together with HP$\beta-C D$ in a molar ratio of $(1: 1 \mathrm{M})$ was dispersed in ethanol for 36 hours using a laboratory shaker at room temperature $\left(25^{\circ} \mathrm{C}\right)$. Non-clinical murine pharmacological tests were performed for anxiety assessment in experimental and control groups. To assess anxiety and motor impairment, the animals were evaluated using the elevated plus maze, open field, and rota-rod tests. Satisfactory results of the anxiolytic effect of the OEC complexed in HP- $\beta$-CD were observed, with the indication of an potentiation of the effect with doses lower than $500 \mathrm{mg} / \mathrm{kg}$ and $250 \mathrm{mg} / \mathrm{kg}$ complexed, suggesting improvement in the anxiolytic properties of the OEC.
\end{abstract}

Keywords: Anxiety. Volatile Oils. Citrus. Cyclodextrins. Pharmaceutical Technology.

\section{How to cite}

Chaves Neto G, Andrade HHN, Braga JEF, Quintans Júnior LJ, Almeida RN, Diniz MFFM. Non-clinical study of the anxiolytic effect of Citrus aurantium L. essential oil in an inclusion complex with 2-hydroxypropyl- $\beta$ cyclodextrin. Rev Ciênc Farm Básica Apl. 2020;41:e705. https://doi.org/10.4322/2179-443X.0705

\section{INTRODUCTION}

Anxiety has increased significantly in the world population. Many factors have been indicated as responsible for this change, and they include profound economic, social, and cultural change. Anxiety is regarded as a state of tension, apprehension, and discomfort, which originates as a response to imminent internal or external danger, to stress, or to some environmental stimulus (Braga, 2010; Freitas, 2013). 
Study (Karino \& Laros, 2014) point out that manifestations of anxiety depend on how individuals cope with situations they consider challenging. In the presence of an anxietycausing stimulus, the person begins to present unpleasant physiological reactions, the posture becomes tense, the facial expression is stressed, and associated headaches may cause involvement of physiological, behavioral, and cognitive components.

Anxiety disorders are present in most populations studied, yet in the United States, they are among the most prevalent psychiatric conditions. Benzodiazepines have been used in recent years as drugs of choice to treat the various forms of anxiety, and more recently, antidepressants have become an option. Yet, although they have benefits, side effects are frequent and include anterograde amnesia and physical dependence (Sadock, 2012; Viana et al., 2016).

Studies have found that due to the side effects often presented by conventional treatments, up to $43 \%$ of patients with anxiety disorders use some form of complementary therapy. And thus medicinal alternatives which present specific anxiolytic effect, and yet are less harmful to the individual are now being sought (Viana et al., 2016; Ernst, 2006).

In the search for innovative pharmacological alternatives to treat anxiety, various scientific investigations have demonstrated the anxiolytic effects of essential oils. In many countries, essential oils have been traditionally used as folk medicine to treat problems related to the nervous system, especially symptoms of anxiety (Viana et al., 2016; Costa et al., 2013).

Essential oils, obtained from plants through physical processes are volatile. Of species that can be used to treat anxiety, essential oil from Citrus aurantium L. popularly known as "bitter orange" (Rutaceae) (Fernandes Pimenta et al., 2016) contains a majority fraction of limonene. As observed from animal behavior when inhaling Citrus aurantium L. essential oil (CEO), nonclinical rat studies have demonstrated its anxiolytic effects (Leite et al., 2008; Carvalho-Freitas \& Costa, 2002; Pultrini et al., 2006). The effects of CEO in humans have verified those found in research with animals (Fernandes Pimenta et al., 2016; Chaves et al., 2017).

In relation to the use of essential oils, one of the limitations is preservation and storage, this, since most of the components are sensitive to heat and oxidation. In addition, their high volatility makes aromatherapy dosages difficult to standardize.

The inclusion of substances in complexes with HP- $\beta-C D$ has been studied to improve the safety and efficacy of products, since it can increase the solubility, permeability and chemical stability of various compounds, such as essential oils, medicines and volatile products (Nascimento et al., 2015).

The potential use of cyclodextrins as drug carriers has been successfully explored, improving the physicochemical characteristics of drugs. They are cyclic oligosaccharides, obtained by the action of the enzyme cyclodextrin glycosyltransferase by the degradation of starch. Due to its ease of access and low cost, HP- $\beta-C D$ is widely used in the pharmaceutical industry, in addition to its ability to interact with most molecules of pharmaceutical interest (Costa et al, 2019).

The use of complexes with HP- $\beta-C D$ and drugs is important because it presents advantages compared to conventional systems. The present manuscript aims to evaluate the anxiolytic effect of the EOC in an HP- $\beta-C D$ inclusion complex, seeking a system with anxiolytic potential that presents a reduction in the preservation, storage and volatility limitations of the OEC.

\section{MATERIALS AND METHODS}

\subsection{The Citrus aurantium L. and 2-hydroxypropyl- $\beta$-cyclodextrin complex}

Development of the CEO and HP- $\beta-C D$ complex was carried out in partnership with the Neuroscience and Pharmacological Tests Laboratory (LANEF), at Sergipe Federal University of - UFS. 


\subsubsection{Substances}

2-hydroxypropyl- $\beta$-cyclodextrin (HP- $\beta-C D ; C 54 H 102 O 39 ;$ purity $\geq 98 \%$ ) was purchased from Sigma-Aldrich (USA), Diazepam (Sigma -USA), Citrus aurantium L. essential oil (CEO), presenting the following characteristics: chemical composition - 90\% limonene; color - strong yellow to orange; odor - citrus, refreshing and penetrating; aspect: clear liquid; density: $0.8300-0.8500 \mathrm{~g} / \mathrm{mL}$ at $20^{\circ} \mathrm{C}$; refractive index at $20^{\circ} \mathrm{C}: 1.4710-1.4750$; and soluble in ethanol, was purchased from By -Samia Aromatherapy (Brazil).

\subsubsection{Preparation of the Citrus autantium L. essential oil/2-hydroxypropyl- $\beta$ - cyclodextrin inclusion complex}

Preparation of the inclusion complex was performed by lyophilization using the Alpha 12 LDplus lyophilizer. Limonene (LIM), the main CEO compound, and HP- $\beta-C D$ in a molar ratio of 1: $1 \mathrm{M}$ was dispersed in ethanol using a laboratory shaker for 36 hours at room temperature $\left(25^{\circ} \mathrm{C}\right)$, allowing formation and avoiding loss of volatiles to the atmosphere. The solution was frozen at $-20^{\circ} \mathrm{C}$ and lyophilized at $-50^{\circ} \mathrm{C}$. The lyophilized samples were stored in closed containers inside a desiccator (Campos et al., 2019).

A lyophilization method was used to prepare CEO/HP- $\beta$-CD according to the literature (Campos et al., 2019; Lima et al., 2019), distilled water (20 mL) containing 1: 1 molar ratios (CEO: HP- $\beta-C D$ ) was mixed. The solution was stirred using a magnetic stirring device operating at $150 \mathrm{rpm}$ (Quimis Q 261A21, Brazil) at room temperature for 36 hours. After mixing, the solution was frozen to $-50^{\circ} \mathrm{C}$ and lyophilized in a freeze dryer until all moisture was sublimated. The lyophilized powder was stored in closed containers inside a desiccator at $25^{\circ} \mathrm{C}$.

\subsection{Development of the non-clinical study}

A non-clinical pharmacological trial at the Psychopharmacology Laboratory - Health Sciences Center - CCS of Paraíba Federal University of (UFPB) was performed. All experimental procedures were previously analyzed and approved by the Ethics Committee on the Use of Animals (CEUA) of Iperfarm/UFPB, under certificate No. 086/2017. The study was developed according to the ARRIVE guidelines (McGrath et al., 2010).

Swiss mice (Mus musculus), albinos, adults, males, weighing between 25 and 35 grams, and approximately 3 months of age were supplied by the Prof. Thomas George Vivarium CCS/UFPB.

Swiss mice (Mus musculus) were used; albinos, adults, males, weighing between 25 and 35 grams, at approximately 3 months of age, healthy, and supplied by the Prof. Thomas George - CCS/UFPB vivarium.

All were grouped in polyethylene cages, kept under controlled conditions of temperature of $21 \pm 2^{\circ} \mathrm{C}$, obeying a light and dark cycle and absence of stressful noises, and without using any medication. The animals had not previously undergone any procedures, and had free access to food (pellet type) and water, in order to minimize variables.

The animals were randomly divided into groups of 06 according to treatments and later distributed according to evaluation testing. The experimental groups were grouped into the Control group, treated with saline solution; the experimental groups - Citrus $1 \mathrm{~g} / \mathrm{kg}$, Citrus $500 \mathrm{mg} / \mathrm{kg}$ and Citrus $250 \mathrm{mg} / \mathrm{kg}$, treated with Citrus aurantium L. essential oil; the experimental groups - Citrus $/ \beta-C D 1 \mathrm{~g} / \mathrm{kg}$; Citrus $/ \beta-C D 500 \mathrm{mg} / \mathrm{kg}$; Citrus $/ \beta-C D$ $250 \mathrm{mg} / \mathrm{kg}$, treated with Citrus aurantium L. essential oil in a 2-hydroxypropyl- $\beta$ cyclodextrin inclusion complex; the Diazepan $1.0 \mathrm{mg} / \mathrm{kg}$ group, and the pure $\beta$ cyclodextrin group. 


\subsection{Tests}

\subsubsection{Elevated Plus Maze Test (EPM)}

The elevated plus maze (Insight ${ }^{\circledR}$ - model EP 150) is an apparatus made of acrylic, gray in color with four arms, two of which present side walls without covers (called closed arms), and two which are open planks. Each arm is positioned at $90^{\circ}$, and they cross at the center, where the animal is placed (Leite et al., 2008).

The test aims to verify possible anxiolytic or anxiogenic effects of administered substances; anxiolytic drugs lead to increases in the number of entries and time spent in the open arms (Baretta et al., 2012).

At half an hour from administration of the treatments, the animals were taken to the EPM. The animals were individually placed on the central platform facing one of the open arms of the maze. The number of entries and the length of stay in each type of arm were recorded for a period of 5 minutes. Entry into an arm was considered when all four legs of the animal meets were within its boundary (Leite et al., 2008).

\subsubsection{Open field}

The Open field test is carried out in a walled circular arena so that the animal cannot escape. The floor is marked with small squares, which allow quantification of the animal's locomotor activity. High defecation and low locomotor activity indicate the animal's anxiety. The animal's locomotor activity in the center of the open field is used as a more selective measure of anxiety. Locomotor activity in the periphery of the apparatus being normal, suggests that a further increase of time spent on the periphery is a principal indicator of anxiety. The effect of anxiolytic drugs, such as diazepan, has been largely demonstrated in this model (Almeida, 2006).

\subsubsection{Rota-rod test (RRT)}

This test is used to detect motor impairment due to pharmacological agents. The device consists of a non-slip plastic bar, $3.0 \mathrm{~cm}$ in diameter, running at $5 \mathrm{rpm}$. Each mouse is placed on the device to assess its ability to continue on the rotating bar for 1 minute, with a tolerance of up to three falls (Costa et al., 2013; Pultrini et al., 2006).

To avoid disability bias (unrelated to the drug treatments), the animals were evaluated in a routine test, and 24 hours before the start of the experimental procedure the animals performing satisfactorily in the initial evaluation were evaluated in the RRT (Costa et al., 2013).

\subsection{Data analysis}

For statistical analysis of the results, GraphPadPrism (version 6.00, GraphPad Software Inc., San Diego, CA, USA) was used. Quantitative data were subjected to the normality test. With a positive result, the data were compared using analysis of variance (ANOVA) followed by Fisher's exact test, and presented as averages with the standard error in parentheses. The results were considered significant at a level of $95 \%(p \leq 0.05)$.

\section{RESULTS}

After the treatments, the mice were evaluated for the Number of Entries (Figure 1A), and the Length of Stay in the open arms of the Elevated Plus Maze (EPM) (Figure 1B). After a single treatment, the Citrus $1.0 \mathrm{~g} / \mathrm{kg}$, Citrus $/ \beta-C D 1.0 \mathrm{~g} / \mathrm{kg}$, and diazepam $1.0 \mathrm{mg} / \mathrm{kg}$ groups presented a significantly increased $(p<0.0017)$ number of entries in the open arms of the EPM compared to the Control and pure $\beta$-cyclodextrin groups. The mice in the Control group presented an average of $4(0.54)$ entries in the open arms of the maize. Mice in the $\beta$-cyclodextrin group presented an average of $6(1.02)$ entries. The group treated with Citrus aurantium L. essential 
oil $1.0 \mathrm{~g} / \mathrm{kg}$ presented an average of 9 (1.19) entries. The group treated with Citrus/ $\beta-C D$ $1.0 \mathrm{~g} / \mathrm{kg}$ presented an average of $10(1.23)$ entries, as did the group treated with diazepam, with 11 (1.73) entries. There was a significant difference between the Citrus $250 \mathrm{mg} / \mathrm{kg}$ group and the Citrus $/ \beta-C D 250 \mathrm{mg} / \mathrm{kg}$ group; the latter presented a greater number of entries in the open arms.

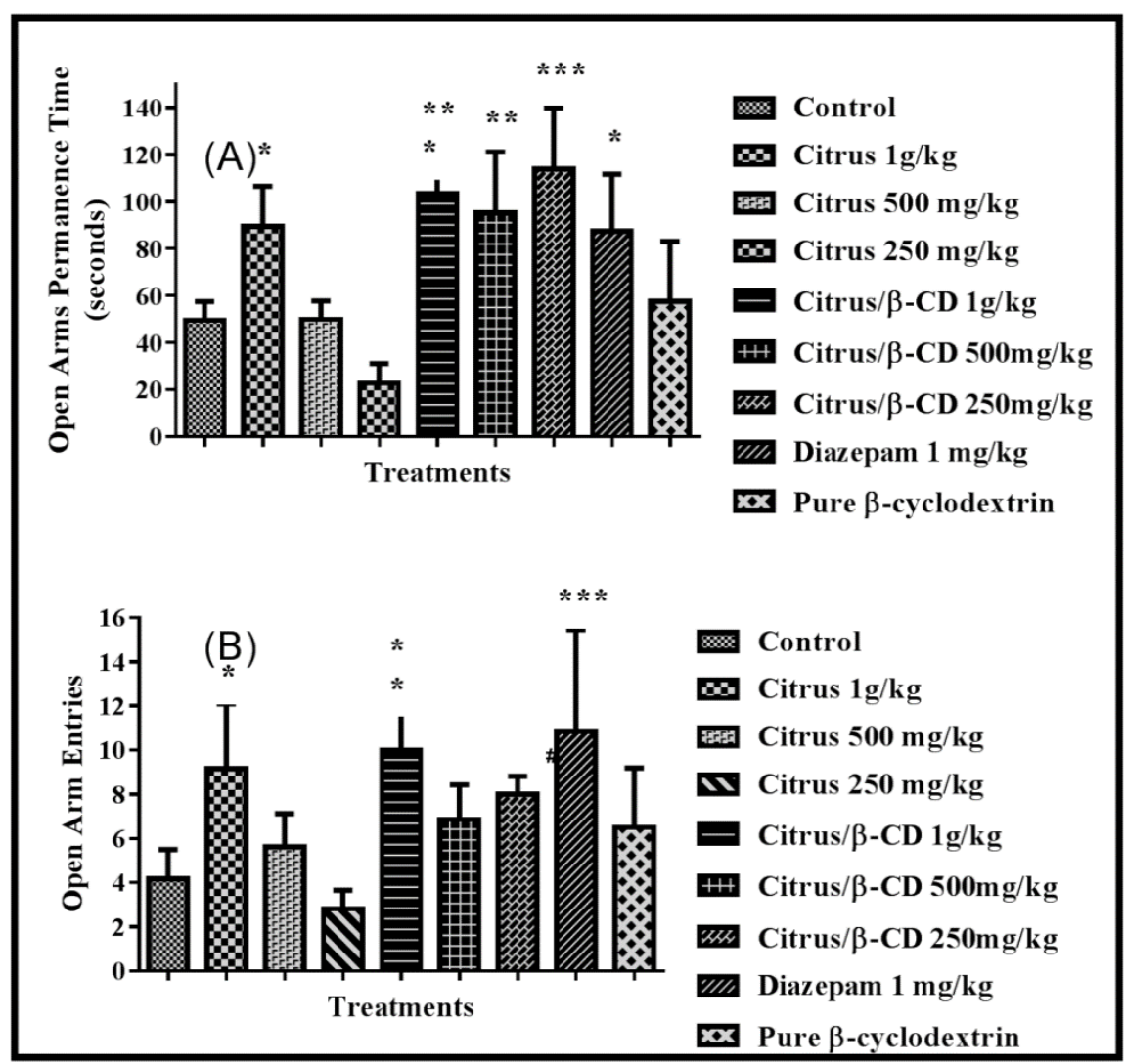

Figure 1. Effects measured in the Elevated Plus Maze test (EPM) after single treatment. Control group: Saline solution; Citrus $1 \mathrm{~g} / \mathrm{kg}$ : Citrus aurantium L. essential oil; Citrus 500 mg/kg: Citrus aurantium L. essential oil; Citrus $250 \mathrm{mg} / \mathrm{kg}$ : Citrus aurantium L. essential oil; Citrus $/ \beta-C D 1 \mathrm{~g} / \mathrm{kg}$ : Citrus aurantium L. essential oil in inclusion complex with 2-hydroxypropyl- $\beta$-cyclodextrin; Citrus/ $\beta-C D 500 \mathrm{mg} / \mathrm{kg}$ : Citrus aurantium $L$. essential oil in inclusion complex with 2 -hydroxypropyl- $\beta$-cyclodextrin; Citrus/ $\beta$-CD $250 \mathrm{mg} / \mathrm{kg}$ : Citrus aurantium L. essential oil in inclusion complex with 2-hydroxypropyl- $\beta$-cyclodextrin;

Diazepam $1.0 \mathrm{mg} / \mathrm{kg}$; Pure $\beta$-cyclodextrin: 2-hydroxypropyl- $\beta$-cyclodextrin. (A) Number of mouse entries into the open arms of the maze; (B) Time of permanence of the mouse in the open arms of the maze. The results are expressed as mean and standard error. * Significant difference $(p \leq 0.05)$ compared to the control group; \# Significant difference $(p \leq 0.05)$ compared to the Citrus $250 \mathrm{mg} / \mathrm{kg}$ group (ANOVA).

As for the permanence time in the EPM open arms (Figure 1B), Citrus $1.0 \mathrm{~g} / \mathrm{kg}$, the three Citrus $/ \beta-C D(1.0 \mathrm{~g} / \mathrm{kg} ; 500 \mathrm{mg} / \mathrm{kg}, 250 \mathrm{mg} / \mathrm{k})$ groups, and diazepam at $1.0 \mathrm{mg} / \mathrm{kg}$ presented significantly increased $(p<0.0001)$ permanence times in the open arms of the EPM as compared to the Control group, Citrus $500 \mathrm{mg} / \mathrm{kg}$, Citrus $250 \mathrm{mg} / \mathrm{kg}$, and the pure $\beta$-cyclodextrin group. The mice in the Control group presented an average of 50 (2.96) seconds in the open arms of the maze, the Citrus group $500 \mathrm{mg} / \mathrm{kg}$ presented an average of 50 (2.81) seconds, the Citrus $250 \mathrm{mg} / \mathrm{kg}$ obtained an average of 23 (2.97) seconds. Mice from the pure $\beta$-cyclodextrin group remained on average 58 (9.04) seconds. The group that received diazepam as a treatment presented an average stay of 87 (9.14) seconds. The group treated 
with CEO $1.0 \mathrm{~g} / \mathrm{kg}$ presented an average stay of $89(6.48)$ seconds. The groups treated with Citrus $/ \beta-C D(1.0 \mathrm{~g} / \mathrm{kg} ; 500 \mathrm{mg} / \mathrm{kg}, 250 \mathrm{mg} / \mathrm{k})$ presented average respective permanence times in seconds of 103 (6.96), 95 (9.35), and 114 (9.17).

The results of the Open Field test are shown in Figure 2. After the treatments, the mice were evaluated for Grooming Time (A), Ambulation Time (B), and Rearing Time (C). After the single treatment, Citrus $/ \beta-C D 500 \mathrm{mg} / \mathrm{kg}$ and diazepam at $1.0 \mathrm{mg} / \mathrm{kg}$ significantly increased $(p<0.0001)$ Grooming Time (A), with an average of 55 (11.44) seconds and 66 (10.68) seconds respectively, as compared to the Control group average of 10 (2.53) seconds, and the Pure $\beta$ cyclodextrin group average of 19 (4.21) seconds. As for Ambulatory Time (B) in the Open Field test, the three groups of Citrus $/ \beta-C D(1.0 \mathrm{~g} / \mathrm{kg} ; 500 \mathrm{mg} / \mathrm{kg}$, and $250 \mathrm{mg} / \mathrm{k})$ and diazepam at $1.0 \mathrm{mg} / \mathrm{kg}$ presented a difference $(p<0.0001)$ from the Control group and the Pure $\beta$ cyclodextrin group. The first three presented respective average ambulation times of 86 (2.96), 86 (4.51), and 98 (5.59) in seconds, the diazepam group presented an average of 132 (18.41) seconds, the control group presented an average of 46 (1.32) seconds, the pure $\beta$ cyclodextrin group presented an average of 52 (4.85) seconds.

Evaluating Rearing time, although a slight increase was observed in the average time of the treated groups, no significant differences attributable to the effect of the studied substances, nor for diazepam, the positive control were observed.

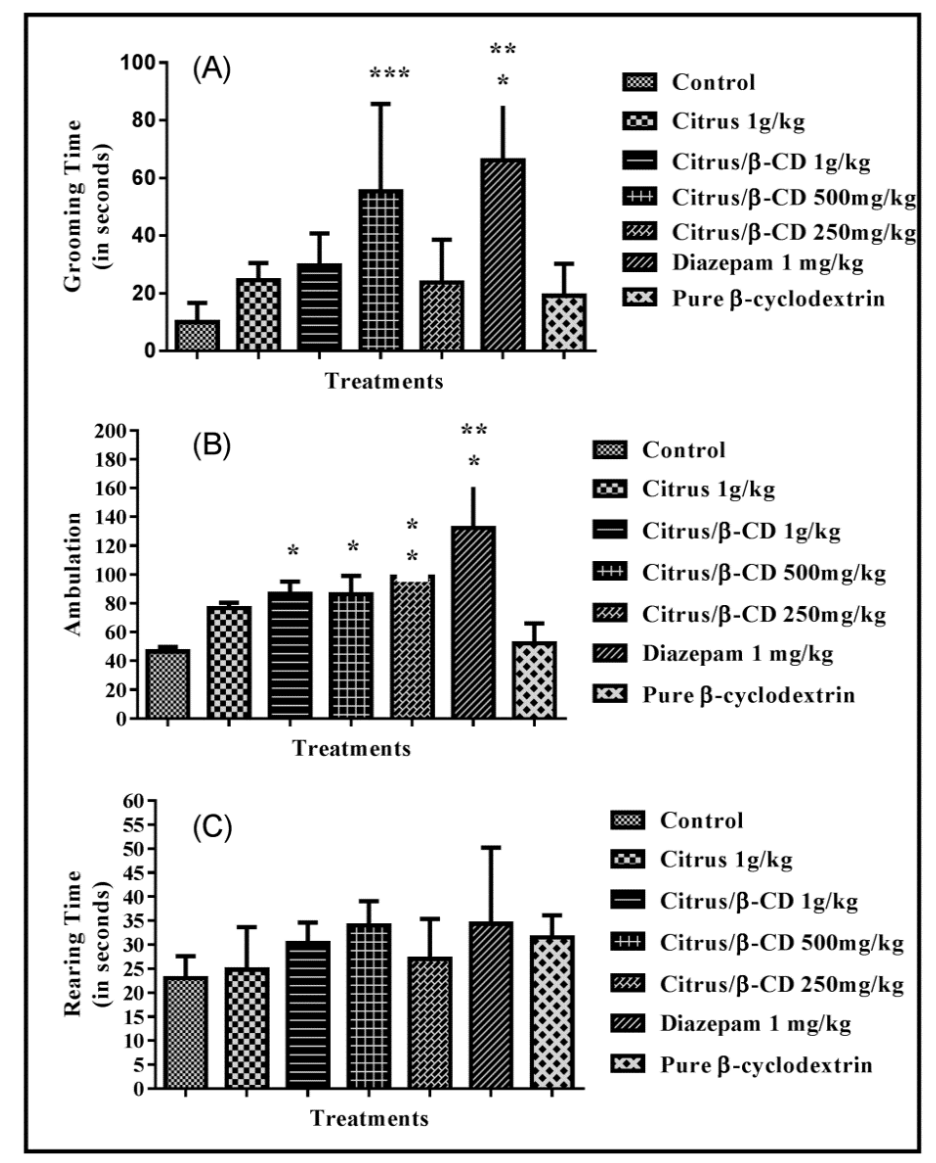

Figure 2-. Effects on Open Field test results after a single treatment. Control: Saline Solution; Citrus 1 g/kg: Citrus aurantium L. essential oil; Citrus/ $\beta-C D 1$ g/kg: Citrus aurantium L. essential oil in an inclusion complex with 2-hydroxypropyl- $\beta$-cyclodextrin; Citrus/ $\beta$-CD 500 mg/kg: Citrus aurantium L. essential oil in an inclusion complex with 2-hydroxypropyl- $\beta$-cyclodextrin; Citrus/ $\beta$-CD $250 \mathrm{mg} / \mathrm{kg}$ : Citrus aurantium L. essential oil in an inclusion complex with 2-hydroxypropyl- $\beta$-cyclodextrin; Diazepam $1.0 \mathrm{mg} / \mathrm{kg}$; Pure $\beta$ cyclodextrin: 2-hydroxypropyl- $\beta$-cyclodextrin. (A) Grooming time in the Open Field; (B) Ambulation time

in the Open Field; $(C)$ Rearing time in the Open Field. * $p \leq 0.05$ as compared to the control group (ANOVA). 
Assessing motor impairment (due to the administered pharmacological agents), there was a longer permanence time recorded for the Control, Citrus $1 \mathrm{~g} / \mathrm{kg}$, Citrus $/ \beta-C D 1 \mathrm{~g} / \mathrm{kg}$, and Pure $\beta$-cyclodextrin groups as compared to diazepam, with a significant difference for the 60 minute (A) and 90 minute (B) time periods (Figure 3). diazepam presents an anxiolytic effect which also interferes with the animal locomotor activity. From measurements of permanence time at 120 minutes from administrations, it was considered that diazepam presented no further effect on the mice, since the statistical difference between the groups was gone, with the mice (in all groups studied) presenting similar permanence time. In the tests performed, no adverse effects were observed that could be attributed to the EO or its complexed form.

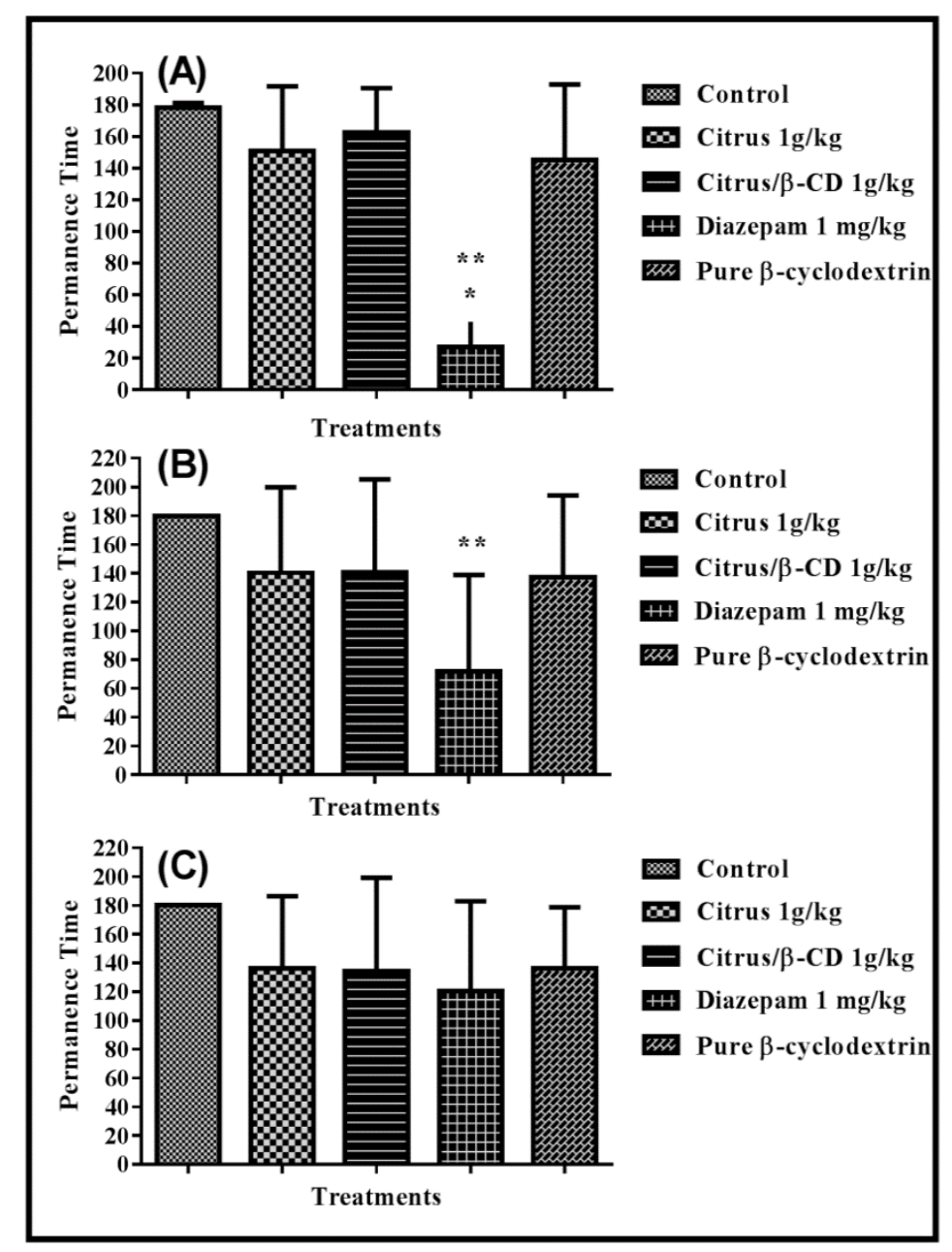

Figure 3. Effects on the Rota Rod test results after a single treatment. Control: Saline solution; Citrus 1 g/kg: Citrus aurantium L. essential oil; Citrus/ $\beta-C D 1$ g/kg: Citrus aurantium L. essential oil in an inclusion complex with 2-hydroxypropyl- $\beta$-cyclodextrin; Diazepam $1.0 \mathrm{mg} / \mathrm{kg}$; Pure $\beta$-cyclodextrin: 2 -

hydroxypropyl- $\beta$-cyclodextrin. (A) Length of stay on the Rota Rod after 60 minutes. (B) Length of stay on the Rota Rod after 90 minutes. $(C)$ Length of stay on the Rota Rod after 120 minutes. * $p \leq 0.05$ compared to the control group (ANOVA).

\section{DISCUSSION}

For the objective of understanding etiological factors, mechanisms, and disease treatments, using animal species as models has been effective despite difficult extrapolation of such results to humans. The limitations for investigating a human disease may involve ethical or aspects inherent to the disease itself, as well as the mode of investigation (Fagundes \& Taha, 2004). Animal models using mice to investigate drugs with an anxiolytic profile are 
considered a viable option, since such models are capable of reproducing behavioral and pathological characteristics interpreted using anxiety syndrome characteristics. The species was chosen based on its biological, behavioral, and genetic makeup (Andreatini et al., 2001; Nunes \& Hallak, 2014).

According to the Brazilian Guideline for the Care and Use of Animals for Scientific and Didactic Purposes (DBCA) of the National Council for Animal Experimentation Control (CONCEA), a reduction in the number of animals used should not be at the expense of loss of reliability in the results. According to the CONCEA definition, the present study is characterized as presenting a low Degree of Invasiveness (GI1); experiments that cause little or no discomfort or stress (Conselho Nacional de Controle de Experimentação Animal, 2013).

The literature presents a variety of essential oils with anxiolytic effects in different animal models. Research highlights Citrus aurantium $\mathrm{L}$., which can be used in different administration routes, with significant effects in various animal models, and with results corroborated by different research groups (de Sousa et al., 2015).

The EPM findings corroborate previous research. Study (Montoya et al., 2008) indicates anxiolytic effect for CEO $(1 \mathrm{~g} / \mathrm{kg})$, as reflected in an increased time spent in the open arms of the EPM, and an increase in the number of and percentage of entries in the open arms. Due to the observed behavior, the authors suggest CEO as an anxiolytic.

The permanence time in the open arms of the EPM was longer in the groups treated with $1.0 \mathrm{~g} / \mathrm{kg}$ Citrus essential oil, the three Citrus $/ \beta-C D$ groups $(1.0 \mathrm{~g} / \mathrm{kg} ; 500 \mathrm{mg} / \mathrm{kg}, 250 \mathrm{mg} / \mathrm{kg}$ ), and diazepam at $1.0 \mathrm{mg} / \mathrm{kg}$, with significant differences from the control group. It is noteworthy that for the length of stay, the $500 \mathrm{mg} / \mathrm{kg}$ and $250 \mathrm{mg} / \mathrm{kg}$ Citrus groups presented no significant differences from the control group, differing from the $500 \mathrm{mg} / \mathrm{kg}$ and $250 \mathrm{mg} / \mathrm{kg}$ groups complexed with $\beta-C D$. This suggests CEO enhancement effects in these presentations.

The results observed, potentiated in groups treated with complexed EOC reiterate the effect of the studied substance and the safety of its complexation, since such effects are not observed with $\beta-C D$ without EOC. Studies demonstrate that the proposed complexation method with $\beta-C D$ is effective, economical and improves the physical-chemical character of limonene, a major component of the EOC (Costa et al., 2019; dos Passos Menezes et al., 2017; Araújo-Filho et al., 2017). Monoterpenes, including limonene, when complexed with $\beta-C D$ and its derivatives present better stability, thus improving efficiency compared to non-complexed monoterpenes, a result attributed to the stability and bioavailability provided by $\beta-C B$ (Brito et al., 2015; de Oliveira et al., 2015).

Study (Lima et al., 2016) attributes that the inclusion of substances in complexes has been able to improve the characteristics of the drug, such as bioavailability, solubility and stability; increasing activity and effectiveness, which corroborates the results presented. Experimental evidence is demonstrated that cyclodextrin improves the anxiolytic properties of OEC, an innovative finding.

In a study using Citral, a monoterpene, and the principal compound found in the essential oil of Cymbopogon citratus, known as "lemongrass", were observed (in animal models) antihyperalgesic and anti-inflammatory effects for Citral/ $\beta$-cyclodextrin inclusion complexes. The samples demonstrated anti-hyperalgesic and anti-inflammatory activity, being due to reductions in total leukocyte levels. Of the samples evaluated, the Citral in $\beta$-cyclodextrin inclusion complexes presented the best pharmacological effects (Campos et al., 2019).

For the EPM tests, the $1.0 \mathrm{~g} / \mathrm{kg}$ Citrus essential oil group, the $1.0 \mathrm{~g} / \mathrm{kg}$ Citrus $/ \beta-C D$ group, and $1.0 \mathrm{mg} / \mathrm{kg}$ diazepam treated mice presented more entries in the open arms, with a significant difference from the control group. A study (Carvalho-Freitas \& Costa, 2002) that evaluated anxiolytic effects in rats exposed by inhalation to essential oil from the shells of Citrus aurantium L., observed safe reductions in anxiety and psychological stress. Corroborating our findings, the essential oil induced a significant increase in the time that the animals remained in the open arms of the maze, as well as a tendency to decrease the time spent in the closed arms, as compared to the control animals. 
Research shows that in addition to finding significant anxiolytic activity in the EOC (Costa et al., 2013), in addition to finding significant anxiolytic activity in the EOC, present results that strongly suggest involvement of $5-\mathrm{HT}$ 1a receptors, a subtype of serotonin receptors. This presents a possible path for EOC activity. Citrus aurantium L. reinforces serotonergic pathways to increase the effect of serotonin in synaptic clefts, this leads to continued tranquility and reduced anxiety in the laboratory animals (Saketi et al., 2014).

It is noteworthy when observing the multiple comparisons of the test, the $250 \mathrm{mg} / \mathrm{kg}$ Citrus/ $\beta$-CD group presented a higher number of entries into the open arms of the EPM than the $250 \mathrm{mg} / \mathrm{kg}$ Citrus group, presenting a significant difference, and reiterating the potentiation effect of the complexed Citrus essential oil presentation. Researchers (Camargo et al., 2018), evaluated the cardiovascular effects of Linalool, (a monoterpene alcohol present in certain aromatic medicinal plants with biological activity), when complexed in $\beta$-cyclodextrin. The Linalool in $\beta$-Cyclodextrin inclusion complex produced a higher antihypertensive profile than the non-complexed form, suggesting potent antihypertensive effects important to cardiovascular activity.

In the Open Field test, Citrus $/ \beta-C D(500 \mathrm{mg} / \mathrm{kg})$ and diazepam at $(1 \mathrm{~g} / \mathrm{kg})$ significantly increased the Grooming Time of the mice as compared to the Control group and the $\beta-C D$ Pure group. In rodents, grooming involves thermoregulation, hair hygiene, and socialization. Grooming stands out most for its relationship to stress, when it occurs, and is potentially informative for studies in animal anxiety (Kalueff et al., 2016).

A study carried out with mice exposed to the open field test (Estanislau et al., 2013), observing mice in an open field test, observed a situation of declining averseness over time, (habituation might reduce averseness), the animals presented less grooming activity at the beginning of the test, with gradual increases of up to about half of the session's duration. Exposures at different levels are highlighted for appearing to produce different effects on grooming, increased anxiety, and/or fear, stimulation of the amygdala circuit, and administration of anxiogenic drugs, would likely prevent grooming.

As for Ambulation Time in the open field, the three groups: Citrus $/ \beta-C D(1.0 \mathrm{~g} / \mathrm{kg}, 500 \mathrm{mg} / \mathrm{kg}$, and $250 \mathrm{mg} / \mathrm{kg}$ ), and diazepam at $1.0 \mathrm{mg} / \mathrm{kg}$ presented significant differences from the Control and the pure $\beta-C D$ groups. There was no increase in ambulation for the $1.0 \mathrm{~g} / \mathrm{kg}$ Citrus group; this implies possible potentiation of the effect of Citrus aurantium L. when in the HP- $\beta-C D$ complex. It also corroborates the findings (Leite et al., 2008), did not observed no changes in relation to the ambulation of a group treated with CEO and the control group; rearings and freezing times revealed no changes as well.

Research with CEO in humans is promising, in a study carried out with patients with chronic myeloid leukemia (in the moments preceding collection of spinal material), it was observed that patients inhaling CEO present a decrease in anxiety and remain relaxed during the procedure (8). Evaluating CEO inhaled by crack users (in abstinence), study (12), demonstrated the anxiolytic effect of the oil in a group living daily with anxiety in different levels. The problem of anxiety is faced during the period of abstinence, maintenance, and final abandonment of drugs. A clinical study presented the effectiveness of aromatherapy using CEO for premenstrual syndrome (PMS); it may well be effective as a new therapeutic method for the emotions and symptoms of PMS (Heydari et al., 2018).

The rota rod test results in the present research demonstrate that CEO alone, and in the HP- $\beta$-CD complex as well, presents anxiolytic effects without motor impairment in the mice. The literature (Carvalho-Freitas \& Costa, 2002) shows that mice treated with the same doses of CEO, presented no impairment in spontaneous ambulation. Another study (Pultrini et al., 2006) also concluded that CEO presents anxiolytic activity in rodents, yet without motor impairment, even after 15 consecutive days of treatment.

This is a non-clinical study, so all data are preliminary, needing more in-depth studies for greater solidity of the results presented. In the clinic, anxiety is diagnosed and evaluated mainly by patients' reports, indicating the subjective nature, which brings a limitation to 
animal models of anxiety. The use of fewer animals in the present study is also one of its limitations, for being a representative sample, for obtaining reliable results.

\section{CONCLUSION}

Satisfactory results for the anxiolytic effect of CEO complexed with HP- $\beta$-CD were observed, an important finding for ensured dose administration without losses due to volatility. The study also indicates a potentiation effect for doses lower than $500 \mathrm{mg} / \mathrm{kg}$ and $250 \mathrm{mg} / \mathrm{kg}$ when complexed, suggesting lower losses of active ingredient during the pharmacokinetic process. It is also noteworthy that motor impairment was not affected; a desired finding for a substance with anxiolytic action. The development of a CEO/HP- $\beta-C D$ complex with positive anxiolytic results in animals is promising for future research and development of medicines for humans.

\section{ACKNOWLEDGMENTS}

This study was supported by funds from the Coordination for the Improvement of Higher Education Personnel (CAPES).

\section{REFERENCES}

Almeida R. Psicofarmacologia: fundamentos práticos. São Paulo: Guanabara Koogan; 2006. 384 p.

Andreatini R, Boerngen-Lacerda R, Zorzetto D Fo. Tratamento farmacológico do transtorno de ansiedade generalizada: perspectivas futuras. Rev Bras Psiquiatr. 2001;23(4):233-42. http://dx.doi.org/10.1590/S1516-44462001000400011.

Araújo-Filho HG, Pereira EWM, Rezende MM, Menezes PP, Araújo AAS, Barreto RSS, Martins AOBPB, Albuquerque TR, Silva BAF, Alcantara IS, Coutinho HDM, Menezes IRA, Quintans-Júnior LJ, Quintans JSS. D-limonene exhibits superior antihyperalgesic effects in a $\beta$-cyclodextrin-complexed form in chronic musculoskeletal pain reducing Fos protein expression on spinal cord in mice. Neuroscience. 2017;358:158-69. http://dx.doi.org/10.1016/j.neuroscience.2017.06.037. PMid:28673718.

Baretta IP, Felizardo RA, Bimbato VF, dos Santos MG, Kassuya CA, Gasparotto A Jr, da Silva CR, de Oliveira SM, Ferreira J, Andreatini R. Anxiolytic-like effects of acute and chronic treatment with Achillea millefolium L. extract. J Ethnopharmacol. 2012;140(1):46-54. http://dx.doi.org/10.1016/j.jep.2011.11.047. PMid:22155391.

Braga JEF. Ansiedade patológica: bases neurais e avanços na abordagem psicofarmacológica. Rev Bras Ciênc Saúde [Internet]. 2010 [cited 2020 Jun 2];14(2):93-100. Available from: http://periodicos.ufpb.br/ojs2/index.php/rbcs

Brito RG, Araújo AAS, Quintans JSS, Sluka KA, Quintans LJ. Enhanced analgesic activity by cyclodextrins A systematic review and meta-analysis. Expert Opinion on Drug Delivery. 2015;12(10):1677-88. https://doi.org/10.1517/17425247.2015.1046835.

Camargo SB, Simões LO, Medeiros CFA, de Melo Jesus A, Fregoneze JB, Evangelista A, Villarreal CF, Araújo AAS, Quintans-Júnior LJ, Silva DF. Antihypertensive potential of linalool and linalool complexed with $\beta$-cyclodextrin: effects of subchronic treatment on blood pressure and vascular reactivity. Biochem Pharmacol. 2018;151:38-46. http://dx.doi.org/10.1016/j.bcp.2018.02.014. PMid:29454617.

Campos CA, Lima BS, Trindade GGG, Souza EPBSS, Mota DSA, Heimfarth L, Quintans JSS, QuintansJúnior LJ, Sussuchi EM, Sarmento VHV, Carvalho FMS, Marreto RN, Costa RMR, Nunes RS, Araújo AAS, Shanmugam S, Thangaraj P. Anti-hyperalgesic and anti-inflammatory effects of citral with $\beta$ cyclodextrin and hydroxypropyl- $\beta$-cyclodextrin inclusion complexes in animal models. Life Sci. 2019;229(May):139-48. http://dx.doi.org/10.1016/j.Ifs.2019.05.026. PMid:31085246.

Carvalho-Freitas MIR, Costa M. Anxiolytic and sedative effects of extracts and essential oil from Citrus aurantium L. Biol Pharm Bull. 2002;25(12):1629-33. https://doi.org/10.1248/bpb.25.1629.

Chaves G No, Braga JEF, Alves MF, de Morais Pordeus LC, Santos SG, Scotti MT, Almeida RN, Diniz MFFM. Anxiolytic effect of citrus aurantium L. in crack users. Evidence-based Complement Altern Med. 2017;2017:7217619. http://dx.doi.org/10.1155/2017/7217619. PMid:29234424. 
Conselho Nacional de Controle de Experimentação Animal - CONCEA. Diretriz Brasileira para o cuidado e a utilização de animais para fins científicos e didáticos (DBCA) do Conselho Nacional de Controle de Experimentação Animal. Brasilia: CONCEA; 2013. p. 1-50.

Costa CARA, Cury TC, Cassettari BO, Takahira RK, Flório JC, Costa M. Citrus aurantium L. essential oil exhibits anxiolytic-like activity mediated by 5-HT1A-receptors and reduces cholesterol after repeated oral treatment. BMC Complement Altern Med. 2013;13(42):1-10. http://dx.doi.org/10.1186/1472-6882-13-42. PMid:23432968.

Costa MDS, Rocha JE, Campina FF, Silva ARP, Da Cruz RP, Pereira RLS, Quintans-Júnior LJ, De Menezes IRA, De S. Araújo AA, De Freitas TS, Teixeira AMR, Coutinho HDM. Comparative analysis of the antibacterial and drug-modulatory effect of $d$-limonene alone and complexed with $\beta$-cyclodextrin. Eur J Pharm Sci. 2019;128:158-61. http://dx.doi.org/10.1016/j.ejps.2018.11.036. PMid:30508582.

de Oliveira MG, Guimarães AG, Araújo AA, Quintans JS, Santos MR, Quintans-Júnior LJ. Cyclodextrins: improving the therapeutic response of analgesic drugs: a patent review. Expert Opinion on Therapeutic Patents. 2015;25(8):897-907. https://doi.org/10.1517/13543776.2015.1045412.

de Sousa D, Hocayen P, Andrade L, Andreatini R. A systematic review of the anxiolytic-like effects of essential oils in animal models. Molecules. 2015 Oct 14;20(10):18620-60. http://dx.doi.org/10.3390/molecules201018620.

dos Passos Menezes P, dos Santos PBP, Dória GAA, de Sousa BMH, Serafini MR, Nunes PS, QuintansJúnior LJ, de Matos IL, Alves PB, Bezerra DP, Mendonça Júnior FJ, da Silva GF, de Aquino TM, de Souza Bento E, Scotti MT, Scotti L, de Souza Araujo AA. Molecular modeling and physicochemical properties of supramolecular complexes of Limonene with $\alpha$ - and $\beta$-Cyclodextrins. AAPS PharmSciTech. 2017;18(1):49-57. http://dx.doi.org/10.1208/s12249-016-0516-0. PMid:27073031.

Ernst E. Herbal remedies for anxiety - A systematic review of controlled clinical trials. Phytomedicine. 2006;13(3):205-8.

Estanislau C, Díaz-Morán S, Cañete T, Blázquez G, Tobeña A, Fernández-Teruel A. Context-dependent differences in grooming behavior among the NIH heterogeneous stock and the Roman high- and low-avoidance rats. Neurosci Res. 2013;77(4):187-201. http://dx.doi.org/10.1016/j.neures.2013.09.012. PMid:24120686.

Fagundes DJ, Taha MO. Modelo animal de doença: critérios de escolha e espécies de animais de uso corrente. Acta Cir Bras. 2004 Jan;19(1):59-65. http://dx.doi.org/10.1590/S0102-86502004000100010.

Fernandes Pimenta FC, Alves MF, Fernandes Pimenta MB, Linhares Melo SA, Figueiredo de Almeida AA, Leite JR, Clebia de Morais Pordeus L, Formiga Melo Diniz, MF, de Almeida RN. Anxiolytic effect of Citrus aurantium L. on patients with chronic myeloid Leukemia. Phyther Res. 2016 Apr 1;30(4):613-7. http://dx.doi.org/10.1002/ptr.5566.

Freitas F F. Avaliação dos efeitos psicofisiológicos da I-teanina em modelo de ansiedade em humanos [dissertação]. João Pessoa: Universidade Federal da Paraíba; 2013 [cited 2020 Jun 2]. Available from: https://repositorio.ufpb.br/handle/tede/4291

Heydari N, Abootalebi M, Jamalimoghadam N, Kasraeian M, Emamghoreishi M, Akbarzadeh M. Investigation of the effect of aromatherapy with Citrus aurantium blossom essential oil on premenstrual syndrome in university students: a clinical trial study. Complement Ther Clin Pract. 2018;32:1-5. http://dx.doi.org/10.1016/j.ctcp.2018.04.006. PMid:30057033.

Kalueff AV, Stewart AM, Song C, Berridge KC, Graybiel AM, Fentress JC. Neurobiology of rodent selfgrooming and its value for translational neuroscience. Nat Rev Neurosci. 2016;17:45-59.

Karino CA, Laros JA. Ansiedade em situações de prova: evidências de validade de duas escalas. PsicoUSF [online]. 2014;19(1):23-36. http://dx.doi.org/10.1590/S1413-82712014000100004.

Leite MP, Fassin J Jr, Baziloni EMF, Almeida RN, Mattei R, Leite JR. Behavioral effects of essential oil of Citrus aurantium L. inhalation in rats. Brazilian J Pharmacogn. 2008;18(Suppl.):661-6. http://dx.doi.org/10.1590/S0102-695X2008000500003.

Lima BS, Campos CA, da Silva Santos ACR, Santos VCN, Trindade GDGG, Shanmugam S, Pereira EWM, Marreto RN, Duarte MC, Almeida JRGDS, Quintans JSS, Quintans LJ Jr, Araújo AAS. Development of morin/hydroxypropyl- $\beta$-cyclodextrin inclusion complex: enhancement of bioavailability, antihyperalgesic and anti-inflammatory effects. Food Chem Toxicol. 2019;126:15-24. http://dx.doi.org/10.1016/j.fct.2019.01.038. PMid:30738132.

Lima PSS, Lucchese AM, Araújo-Filho HG, Menezes PP, Araújo AAS, Quintans-Júnior LJ, Quintans JSS. 
Inclusion of terpenes in cyclodextrins: preparation, characterization and pharmacological approaches. Carbohydr Polym. 2016;151:965-87. http://dx.doi.org/10.1016/j.carbpol.2016.06.040. PMid:27474645.

McGrath J, Drummond G, McLachlan E, Kilkenny C, Wainwright C. Guidelines for reporting experiments involving animals: the ARRIVE guidelines. Br J Pharmacol. 2010 Aug 1;160(7):1573-6. http://dx.doi.org/10.1111/j.1476-5381.2010.00873.x.

Montoya C, Moreno E, Romero MaL, Torales J, Centurión C. U. El uso del laberinto en cruz elevado para medir los efectos ansiolíticos producidos por el citrus auriantum L.(petit grain) en los ratones. Med Actual. 2008;9(1):8-12.

Nascimento JAC Jr, de Almeida LN, Silva CML, Serafini MR. Analysis of recent patent applications involving cyclodextrins the pharmaceutical industry. Rev Interdiscip Pesqui e Inovação. 2015;1:1-11.

Nunes EA, Hallak JEC. Modelos animais em psiquiatria: Avanços e desafios. Rev Latinoam Psicopatol Fundam. 2014 Sep 1;17(3):528-43. http://dx.doi.org/10.1590/1415-4714.2014v17n3p528-10.

Pultrini AM, Galindo LA, Costa M. Effects of the essential oil from Citrus aurantium L. in experimental anxiety models in mice. Life Sci. 2006;78(15):1720-5. http://dx.doi.org/10.1016/j.lfs.2005.08.004. PMid:16253279.

Sadock BJ. Inevitable suicide. J Psychiatr Pract. 2012 May;18(3):221-4. http://dx.doi.org/10.1097/01.pra.0000415080.51368.cf.

Saketi S, Bananej M, Jahromy MH. Effect of Citrus aurantium L. Essential oil and its interaction with fluoxetine on anxiety in male mice. J Behav Brain Sci. 2014;4(7):285-90. http://dx.doi.org/10.4236/jbbs.2014.47029.

Viana MDM, Vieira ACS, Silva GJ No, Póvoas FTX, Campesatto EA. Potencial ansiolítico do gênero citrus : revisão integrativa. Rev Cient da Unipar. 2016;20(1):73-9. https://doi.org/10.25110/arqsaude.v20i1.2016.4851.

\section{Authors' contributions}

Neto GC proceeded to the development of the research and the writing of the manuscript. Neto GC, Andrade HHN and Braga JEF contributed to the writing of the manuscript and participated in the process of data collection, analysis and interpretation of the data. Júnior LJQ contributed with Inclusion complex analysis. Diniz MFFM and Almeida RN contributed to the critical review and final writing of the manuscript 